\title{
Stalagmite water content as a proxy for drip water supply in tropical and subtropical areas
}

\author{
N. Vogel ${ }^{1,2}$, Y. Scheidegger ${ }^{1,2}$, M. S. Brennwald ${ }^{1}$, D. Fleitmann ${ }^{3,4, *}$, S. Figura ${ }^{1,5}$, R. Wieler ${ }^{2}$, and R. Kipfer ${ }^{1,2,5}$ \\ ${ }^{1}$ Eawag, Swiss Federal Institute of Aquatic Science and Technology, Überlandstrasse 133, 8600 Dübendorf, Switzerland \\ ${ }^{2}$ ETH Zurich, Institute of Geochemistry and Petrology, Clausiusstrasse 25, 8092 Zurich, Switzerland \\ ${ }^{3}$ Institute of Geological Sciences, University of Bern, Baltzerstrasse 1-3, 3012 Bern, Switzerland \\ ${ }^{4}$ Oeschger Center for Climate Research, University of Bern, Zähringerstrasse 25, 3012 Bern, Switzerland \\ ${ }^{5}$ ETH Zurich, Institute of Biogeochemistry and Pollutant Dynamics, Universitätsstrasse 16, 8092 Zurich, Switzerland \\ *now at: Department of Archaeology, School of Human and Environmental Sciences, University of Reading, \\ Whiteknights, P.O. Box 226, Reading, RG6 6AB, UK
}

Correspondence to: N. Vogel (nadia.vogel@eawag.ch)

Received: 15 June 2012 - Published in Clim. Past Discuss.: 25 July 2012

Revised: 3 December 2012 - Accepted: 4 December 2012 - Published: 7 January 2013

\begin{abstract}
In this pilot study water was extracted from samples of two Holocene stalagmites from Socotra Island, Yemen, and one Eemian stalagmite from southern continental Yemen. The amount of water extracted per unit mass of stalagmite rock, termed "water yield" hereafter, serves as a measure of its total water content. Based on direct correlation plots of water yields and $\delta^{18} \mathrm{O}_{\text {calcite }}$ and on regime shift analyses, we demonstrate that for the studied stalagmites the water yield records vary systematically with the corresponding oxygen isotopic compositions of the calcite $\left(\delta^{18} \mathrm{O}_{\text {calcite }}\right)$. Within each stalagmite lower $\delta^{18} \mathrm{O}_{\text {calcite }}$ values are accompanied by lower water yields and vice versa. The $\delta^{18} \mathrm{O}_{\text {calcite }}$ records of the studied stalagmites have previously been interpreted to predominantly reflect the amount of rainfall in the area; thus, water yields can be linked to drip water supply. Higher, and therefore more continuous drip water supply caused by higher rainfall rates, supports homogeneous deposition of calcite with low porosity and therefore a small fraction of water-filled inclusions, resulting in low water yields of the respective samples. A reduction of drip water supply fosters irregular growth of calcite with higher porosity, leading to an increase of the fraction of water-filled inclusions and thus higher water yields. The results are consistent with the literature on stalagmite growth and supported by optical inspection of thin sections of our samples. We propose that for a stalagmite from a dry tropical or subtropical area, its water yield record represents a novel paleo-climate proxy
\end{abstract}

recording changes in drip water supply, which can in turn be interpreted in terms of associated rainfall rates.

\section{Introduction}

Stalagmites have been recognised as distinguished paleoclimate archives as they occur widespread in continental settings, are precisely dateable, and preserve a wealth of highresolution paleo-climate information over long time intervals (e.g. Cheng et al., 2009; Dong et al., 2010; Fleitmann et al., 2003a, 2007; Henderson, 2006; Wang et al., 2008; Zhao et al., 2010). For paleo-climate reconstructions, stalagmite studies often focus on changes in the isotopic compositions of oxygen and carbon of the calcite $\left(\delta^{18} \mathrm{O}_{\text {calcite }}, \delta^{13} \mathrm{C}_{\text {calcite }}\right)$ to identify major climatic events (e.g. Burns et al., 2001; Fleitmann et al., 2009; Liu et al., 2010), to reconstruct changes in precipitation (e.g. Griffith et al., 2010; Vaks et al., 2010), and to infer type and density of plant cover above a cave (e.g. Cosford et al., 2009; Dorale et al., 1998). However, our understanding of the true sensitivity of $\delta^{18} \mathrm{O}_{\text {calcite }}$ and $\delta^{13} \mathrm{C}_{\text {calcite }}$ values to climatic and environmental variables remains limited and interpretation of speleothem stable isotope records is therefore often controversial (e.g. Clemens et al., 2010; LeGrande and Schmidt, 2009; McDermott et al., 2006). A way to reduce these uncertainties is to measure additional climate-sensitive parameters in speleothems, e.g. in 
the drip water trapped in fluid inclusions during stalagmite growth. The hydrogen isotopic composition of inclusion water (in combination with corresponding $\delta^{18} \mathrm{O}_{\text {calcite }}$ ) has been used to reconstruct paleo-temperatures (Zhang et al., 2008) and changes in the source and amount of rainfall (e.g. Fleitmann et al., 2003b; Harmon et al., 1979; McGarry et al., 2004; Schwarcz and Harmon, 1976). More recently, concentrations of noble gases dissolved in inclusion water have been used to determine absolute temperatures prevailing in a cave during stalagmite growth (Kluge et al., 2008; Scheidegger et al., 2010, 2011). These so-called noble gas temperature determinations require the quantification of the amount of water from which the dissolved noble gases are released. In the course of noble gas temperature determinations on samples from two Holocene stalagmites from Socotra Island (Yemen), we observed that the amounts of water extracted per unit mass of stalagmite rock (the "water yields") vary systematically with the respective stalagmites' $\delta^{18} \mathrm{O}_{\text {calcite }}$ (cf. Scheidegger, 2011), which has previously been shown to reflect changes in the rates of rainfall, i.e. was attributed to the so-called "amount effect" (Fleitmann et al., 2007). This effect was originally proposed by Dansgaard (1964) and is based on the observation that in tropical and subtropical monsoon regions, stronger (i.e. higher rates of) monsoon rainfall often exhibits more negative $\delta^{18} \mathrm{O}$ signals than weaker monsoon rainfall, a feature that is best observed in arid regions (Clark and Fritz, 1997). As shown, e.g. by Fleitmann et al. (2004), the $\delta^{18} \mathrm{O}$ of the rainfall is reflected in that of the stalagmite's calcite as long as no massive changes of other parameters occur that would influence $\delta^{18} \mathrm{O}_{\text {calcite, }}$, which can largely be excluded for the relevant time span on Socotra Island. A co-variation of water yield and $\delta^{18} \mathrm{O}_{\text {calcite }}$ was also observed in a stalagmite grown during the Eemian in southern continental Yemen. Also for this stalagmite, the $\delta^{18} \mathrm{O}_{\text {calcite }}$ record was found to reflect mainly changes in rainfall rates (Fleitmann et al., 2011b). Therefore, we propose that in dry tropic to subtropic areas, the stalagmite's water yield represents a new paleo-climate proxy responding to long-term changes in drip water supply. Only recently, a similar suggestion was made based on stalagmite water content measurements on a Hungarian stalagmite (Demény et al., 2012).

\section{Experimental procedures}

\subsection{Sampling sites}

Figure 1 shows the locations of the caves from where the three studied stalagmites originate. Stalagmites D1 and P3 were taken from Dimarshim Cave and Pit Cave, respectively, located on opposite sides of the central mountain range of Socotra Island, Yemen. Socotra lies in the NW Indian Ocean, about $240 \mathrm{~km}$ east of the Horn of Africa and $380 \mathrm{~km}$ south of the Arabian Peninsula. The modern climatic conditions on

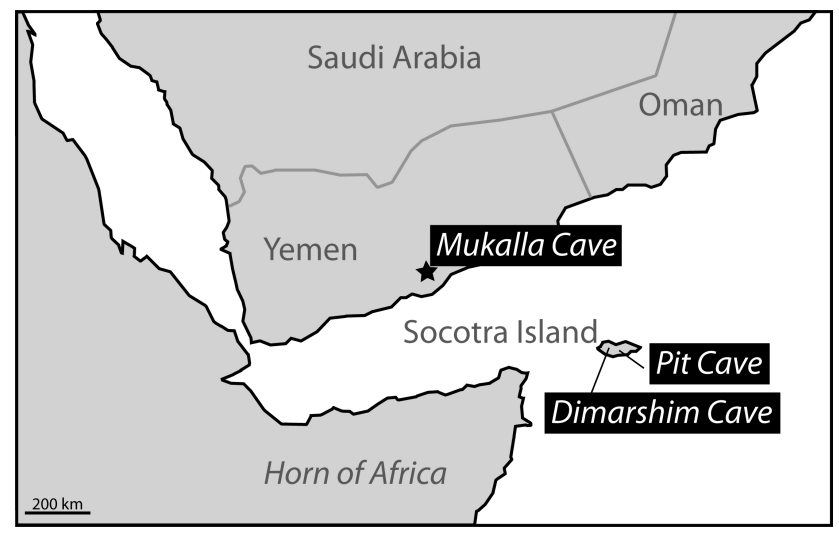

Fig. 1. Overview map showing Yemen with Socotra Island and the locations of Mukalla Cave, Dimarshim Cave, and Pit Cave.

the island are semi-arid and characterized by seasonally reversing monsoon winds (Scholte and De Geest, 2010). Rainfall is associated with the passing of the Intertropical Convergence Zone over the island, resulting in a mean annual amount of rainfall of approximately $300 \mathrm{~mm}$ (Fleitmann et al., 2007; Scholte and De Geest, 2010; Shakun et al., 2007). Stalagmite Y99 was taken from Mukalla Cave (see Fleitmann et al., 2011b) situated in southern continental Yemen, an area that is also influenced by the monsoon. However, present-day rates of rainfall in the Mukalla Cave region are considerably lower than on Socotra Island and the area is characterized by arid to hyper-arid climatic conditions.

\subsection{Dating}

Absolute ages for all studied stalagmites are based on Uranium-series dating ( ${ }^{230} \mathrm{Th}$-dating hereafter). Details on the analytical method and results are provided by Fleitmann et al. $(2007,2011 \mathrm{~b})$. Age models for D1 and Y99 were constructed by linear interpolation between measured ${ }^{230} \mathrm{Th}$ ages. A total of eight ${ }^{230} \mathrm{Th}$ ages (see Fig. 2) indicate that stalagmite D1 grew continuously with a mean growth rate of $0.25 \mathrm{~mm} \mathrm{a}^{-1}$ over the last $4.5 \mathrm{ka}$. Stalagmite Y99 records several growth periods separated by hiatuses (Fleitmann et al., 2011b). For this study the growth period between 119 and $131 \mathrm{ka} \mathrm{BP}$ was analyzed. During this period, Y99 grew at a mean growth rate of about $0.013 \mathrm{~mm} \mathrm{a}^{-1}$ as deduced from a total of seven ${ }^{230} \mathrm{Th}$ ages. The studied part of the stalagmite is separated from older parts by a distinct change in calcite texture and colour. Photographs of stalagmite Y99 including locations for dating can be found in Fig. 2 in Fleitmann et al. (2011b). In this figure, the part of stalagmite Y99 studied here is referred to as Sect. I. Two ${ }^{230} \mathrm{Th}$ ages measured at the top and base of stalagmite P3 (see Table 1 and Fig. 2) indicate that it grew within the time period of about 10 to $1.3 \mathrm{ka} \mathrm{BP}$. A marked change in colour (arrow in Fig. 2) close to the top of P3 indicates a growth hiatus. The existing ages do not allow 


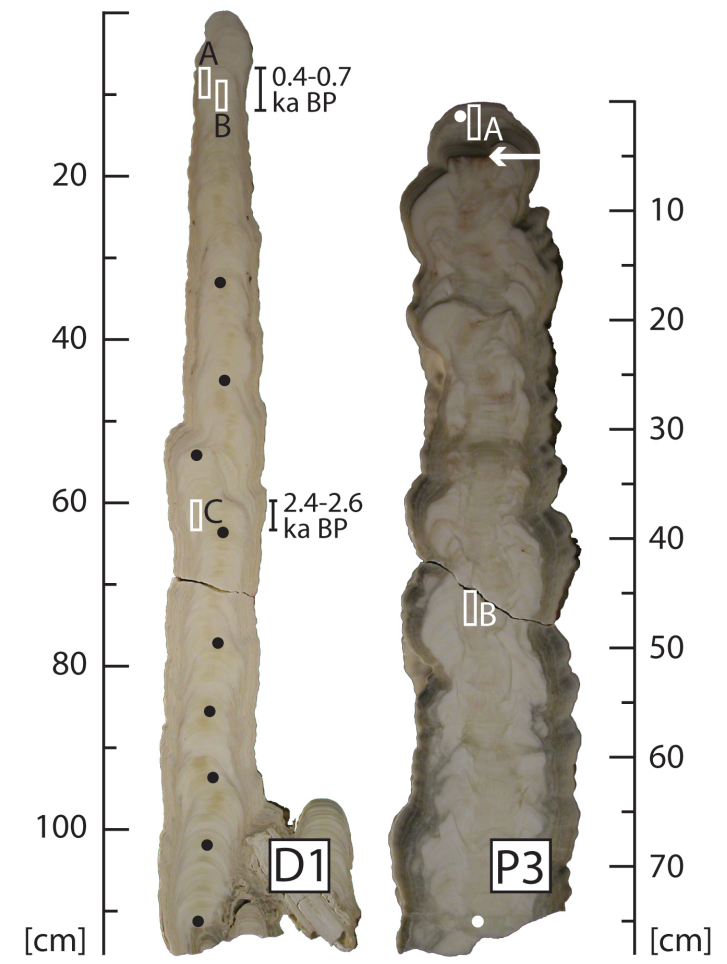

Fig. 2. Photographs of polished sections of stalagmites D1 and P3 cut parallel to their growth axes including locations for ${ }^{230} \mathrm{Th}$ dating (black dots for D1, white dots for P3). The arrow points to a potential growth hiatus in stalagmite $\mathrm{P} 3$. White squares indicate areas from which thin sections for stalagmite D1 (D1-A, -B, -C) and P3 (P3-A, -B) were prepared. For D1 sections also the covered time intervals are given. Photographs for Y99 with locations for dating are presented in Fleitmann et al. (2011b).

drawing conclusions on the timing of the growth hiatus, and the chronology of P3 is thus only poorly constrained.

\subsection{Stable isotope analyses}

Oxygen isotopes for stalagmites $\mathrm{Y} 99$ and $\mathrm{P} 3$ were analyzed on a Finnigan Delta V Advantage mass spectrometer equipped with an automated carbonate preparation system (Gas Bench-II, see Fleitmann et al. (2011b) for analytical details). $\delta^{18} \mathrm{O}_{\text {calcite }}$ measurements of stalagmite D1 were performed on a Delta-plusXL mass spectrometer and are published in Fleitmann et al. (2007). $\delta^{18} \mathrm{O}_{\text {calcite values are pre- }}$ sented as parts per mil (\%o) relative to the Vienna PeeDee Belemnite (VPDB) standard.

\subsection{Water yield measurements}

Inclusion water was extracted from 30 samples of stalagmite D1, 13 samples of stalagmite P3, and 5 samples of stalagmite Y99. The extracted water amounts, i.e. the water yields (defined as the amounts of water extracted per unit mass of stalagmite rock), as well as total water contents (defined as the total amount of water per unit mass of stalagmite rock) are given as mass of water per unit mass of stalagmite rock in Table 2 and throughout the paper. Prior to water extraction, each sample was first crushed to a grain size of about $350 \mu \mathrm{m}$. During this crushing procedure (which is a prerequisite for successful noble gas analyses, see Scheidegger et al., 2010), a fraction of the inclusion water present in the stalagmite sample is probably lost. However, according to Scheidegger et al. (2010) this fraction is minor. Crushed samples (approximately $5 \mathrm{~g}$ for D1 and P3 samples, respectively, and $\leq 1 \mathrm{~g}$ for Y99 samples) were then loaded into a high vacuum water and noble gas extraction system (Scheidegger et al., 2010, 2011). Water was extracted from the grain separates by heating. The extracted amounts of water were then determined by cryogenically concentrating the water into a known volume and measuring the water vapour pressure manometrically following the experimental procedure described by Scheidegger et al. (2010). The overall uncertainties associated with the water yield determinations are given in Table 2 and are discussed in the following. All errors are given at a $1 \sigma$ significance level. The precision of a vapour pressure measurement includes (i) the instrument-specific precision of the pressure measurement $( \pm 0.025 \%)$, (ii) the uncertainty of the ambient temperature determination $( \pm 0.25 \%)$, and (iii) the uncertainty associated with calibrating the "known volume" $( \pm 0.6 \%)$. A bias in the determination of the water mass occurs also if not all of the generated pressure originates from water vapour. This has been extensively tested and discussed in Scheidegger (2011) and Scheidegger et al. (2010). Briefly, at elevated extraction temperatures the liberated water vapour reacts with the metal surfaces of the extraction line, which consumes small amounts of water and builds up a hydrogen pressure, which can be determined when all water is concentrated cryogenically into the known volume. To account for this bias, the residual hydrogen pressure is, if present, (i) deduced from the total measured pressure and is (ii) used as an additional measure of the error of the pressure measurement itself. While this additional error has a minor influence on the overall uncertainty of the $320^{\circ} \mathrm{C}$ water yield uncertainties, which are on average $1.2 \%$, it can be a significant source of error for the $480^{\circ} \mathrm{C}$ water yield measurements, whose errors range around $3 \%$. The errors compare well with the scatter of water yield results from replicate analyses on aliquots of a D1 grain separate $(85-350 \mu \mathrm{m})$, which is $\sim 3 \%$. Note, however, that producing real "aliquots" of such a grain size separate is not easy and the scatter might, to a considerable degree, originate from real differences in the water contents of the "aliquots".

At temperatures above approximately $600^{\circ} \mathrm{C}$, water extraction from the samples is quantitative, as at these temperatures calcite begins to disintegrate into $\mathrm{CaO}$ and $\mathrm{CO}_{2}$ (e.g. Faust, 1950; Yonge, 1982). The generated $\mathrm{CO}_{2}$, however, would significantly disturb the water vapour pressure measurements and even more so subsequent noble gas analyses (see also next section). Therefore, the grain separates 
Table 1. Results of ${ }^{230} \mathrm{Th}$-dating of stalagmite P3 (see Fleitmann et al., 2007 for details on the analytical techniques). * For dating of stalagmites D1 and Y99, see Fleitmann et al. (2007, 2011b).

\begin{tabular}{lrrrrrrr}
\hline Sample & $\begin{array}{r}\text { distance from } \\
\text { top }(\mathrm{cm})\end{array}$ & $\begin{array}{r}\text { Th concen- } \\
\text { tration }(\mathrm{ppb})\end{array}$ & $\begin{array}{r}\mathrm{U} \text { concen- } \\
\text { tration }(\mathrm{ppb})\end{array}$ & ${ }^{234} \mathrm{U} /{ }^{238} \mathrm{U}$ & ${ }^{230} \mathrm{Th} /{ }^{232} \mathrm{Th}$ & $\begin{array}{r}\text { Age } \\
{ }^{230} \mathrm{Th} /{ }^{234} \mathrm{U}\end{array}$ & $\begin{array}{r}(\mathrm{ka} \mathrm{BP}) \\
\hline \text { P3-a }\end{array}$ \\
P3-b & 0.5 & $0.496 \pm 0.007$ & $330.7 \pm 0.9$ & $1.2408 \pm 0.0033$ & $31 \pm 2$ & $0.0123 \pm 0.0007$ & $1.34 \pm 0.09$ \\
& 72.6 & $0.176 \pm 0.001$ & $376 \pm 1$ & $1.2778 \pm 0.0039$ & $760 \pm 11$ & $0.0920 \pm 0.0011$ & $10.5 \pm 0.2$ \\
\hline
\end{tabular}

Table 2. Water in stalagmites D1, P3, and Y99.

\begin{tabular}{|c|c|c|c|c|c|c|c|}
\hline Sample & $\begin{array}{c}\text { Age } \\
{[\mathrm{ka} \mathrm{BP}]}\end{array}$ & $\begin{array}{r}\text { Water yield } \\
320^{\circ} \mathrm{C}\end{array}$ & $\begin{array}{l}\text { Water yield } \\
\text { crushing+heating }\end{array}$ & $\begin{array}{l}\text { from top } \\
\text { Sample }\end{array}$ & $\begin{array}{r}\text { Distance } \\
320^{\circ} \mathrm{C} \\
{[\mathrm{cm}]}\end{array}$ & $\begin{array}{r}\text { Water yield } \\
\text { crushing+heating }\end{array}$ & $\begin{array}{r}\text { Water yield } \\
480^{\circ} \mathrm{C}\end{array}$ \\
\hline D1-1 & 0.04 & $1.96 \pm 0.02$ & & P3-1 & 0.5 & $3.33 \pm 0.04$ & \\
\hline D1-2 & 0.07 & $2.58 \pm 0.03$ & & P3-2 & 0.5 & $3.30 \pm 0.04$ & \\
\hline D1-3 & 0.19 & $1.77 \pm 0.02$ & & P3-3 & 1 & $2.92 \pm 0.04$ & \\
\hline D1-4 & 0.30 & $2.22 \pm 0.03$ & & P3-4 & 2 & $1.80 \pm 0.02$ & $18.3 \pm 0.3$ \\
\hline D1-5 & 0.37 & $2.53 \pm 0.03$ & $26.4 \pm 0.4$ & P3-5 & 3 & $3.55 \pm 0.04$ & \\
\hline D1-6 & 0.74 & $3.31 \pm 0.04$ & & P3-6 & 7.3 & $2.87 \pm 0.03$ & $36.2 \pm 0.3$ \\
\hline D1-7 & 1.60 & $3.02 \pm 0.04$ & & P3_7 & 13 & $2.29 \pm 0.03$ & $13.1 \pm 0.6$ \\
\hline D1-8 & 1.75 & $4.96 \pm 0.08$ & & P3_8 & 20 & $2.13 \pm 0.03$ & \\
\hline D1-9 & 1.80 & $3.50 \pm 0.04$ & & P3_9 & 27 & $2.12 \pm 0.03$ & $23.6 \pm 0.2$ \\
\hline D1-10 & 1.85 & $4.73 \pm 0.06$ & & P3_10 & 41 & $1.58 \pm 0.02$ & \\
\hline D1-11 & 1.89 & $5.85 \pm 0.07$ & & P3_11 & 45 & $0.86 \pm 0.01$ & $7.3 \pm 0.2$ \\
\hline D1-12 & 1.90 & $5.30 \pm 0.06$ & & P3_12 & 51 & $1.72 \pm 0.02$ & \\
\hline D1-13 & 1.95 & $3.76 \pm 0.04$ & & P3_13 & 69 & $2.87 \pm 0.03$ & $28.1 \pm 0.2$ \\
\hline D1-14 & 2.00 & $4.70 \pm 0.06$ & & & & & \\
\hline D1-15 & 2.05 & $3.07 \pm 0.04$ & & & & Water yield & \\
\hline D1-16 & 2.10 & $2.98 \pm 0.04$ & & & Age & $400^{\circ} \mathrm{C}$ & \\
\hline D1-17 & 2.15 & $3.43 \pm 0.04$ & & Sample & {$[\mathrm{ka} \mathrm{BP}]$} & {$\left[10^{-4} \mathrm{~g} \mathrm{~g}^{-1}\right]$} & \\
\hline D1-18 & 2.20 & $3.70 \pm 0.04$ & $32.4 \pm 0.4$ & Y99-1 & 119.7 & $21.3 \pm 0.6$ & \\
\hline D1-19 & 2.37 & $6.00 \pm 0.07$ & & Y99-2 & 119.7 & $21.2 \pm 0.6$ & \\
\hline D1-20 & 2.45 & $4.45 \pm 0.05$ & & Y99-3 & 124.2 & $10.3 \pm 0.2$ & \\
\hline D1-21 & 3.13 & $2.07 \pm 0.02$ & & Y99-4 & 126.5 & $5.98 \pm 0.08$ & \\
\hline D1-22 & 3.14 & $3.75 \pm 0.05$ & & Y99-5 & 129.2 & $7.9 \pm 0.1$ & \\
\hline D1-23 & 3.19 & $5.20 \pm 0.06$ & & & & & \\
\hline D1-24 & 3.49 & $3.74 \pm 0.04$ & $47.4 \pm 0.6$ & & & & \\
\hline D1-25 & 3.72 & $3.88 \pm 0.05$ & & & & & \\
\hline D1-26 & 3.80 & $3.60 \pm 0.04$ & & & & & \\
\hline D1-27 & 4.28 & $4.86 \pm 0.06$ & & & & & \\
\hline D1-28 & 4.32 & $4.30 \pm 0.05$ & $43.0 \pm 0.4$ & & & & \\
\hline D1-29 & 4.53 & $4.55 \pm 0.05$ & & & & & \\
\hline D1-30 & 4.56 & $4.04 \pm 0.05$ & & & & & \\
\hline
\end{tabular}

$\mathrm{D} 1, \mathrm{P} 3$, and Y99 water yields (given in units of $10^{-4} \mathrm{~g}$ of water per $\mathrm{g}$ of stalagmite rock) extracted from grain separates (mean grain diameter $350 \mu \mathrm{m}$ ) at different temperatures. For selected samples of D1 and P3, also the water yield resulting from combined vacuum crushing and subsequent heating of the powder to $480^{\circ} \mathrm{C}$ ("water yield crushing + heating $480^{\circ} \mathrm{C}$ ") is given. Uncertainties of water yield measurements are $1 \sigma$ and are discussed in Sect. $2.4 .^{230} \mathrm{Th}$ age uncertainties are $<3 \%$. For detailed information on the age uncertainties of D1 and Y99, see Fleitmann et al. (2007, 2011b), respectively.

were heated for $1 \mathrm{~h}$ to only $320^{\circ} \mathrm{C}$ (D1 and P3 samples), and $400{ }^{\circ} \mathrm{C}$ (Y99 samples), respectively. The resulting water yields are considerably lower than the total water contents of the samples (cf. Sect. 2.5 and Table 2). This is due to the fact that the water yield is mainly a function of the extraction temperature and duration, but also of the fabric and the grain size spectrum of a given stalagmite sample. Therefore, a direct comparison of water yields is only meaningful for samples taken from the same stalagmite, and only if extraction 
was performed under the same experimental conditions for all samples.

\subsection{Additional water extraction experiments}

In order to further study the relationship between water yield and the total water content of the samples, additional water extraction experiments were performed. Small blocks (1-5 g) were cut from stalagmites D1 and P3 close to the positions of samples used for water yield determinations. This was done to enable a direct comparison of the respective extracted water amounts. The blocks were broken into a few pieces and loaded into a vacuum crusher described by Scheidegger et al. (2010). In a first step, each sample was crushed to a very fine powder (50-80 wt $\%$ of the powder had a grain size of $<85 \mu \mathrm{m}$ ), and the water amount released during crushing was determined. In a second step, this powder was heated to $480^{\circ} \mathrm{C}$ for $1 \mathrm{~h}$ to extract as much water as possible at conditions that still allowed determination of an accurate water vapour pressure. The cumulative water yields extracted during crushing and subsequent heating to $480^{\circ} \mathrm{C}$ are referred to as "water yield crushing + heating $480^{\circ} \mathrm{C}$ " in Table 2 and Fig. 3. For both stalagmites, a correlation was observed between the water yields obtained from extraction at $320^{\circ} \mathrm{C}$ and the combined crushing/heating procedure (Fig. 3). The latter water amounts are systematically higher by about a factor of 10 compared to the former ones. Interestingly, the fractions of water released during crushing alone (i.e. prior to heating the powder to $480^{\circ} \mathrm{C}$ ) are significantly different for D1 and P3 samples. In the case of P3, about $70 \%$ of the extracted water was released by crushing, followed by another $30 \%$ by heating of the crushed sample. For D1 samples, about $40 \%$ of the water was released during crushing and $60 \%$ by subsequent heating.

Subsequent to the $480^{\circ} \mathrm{C}$ heating step, two samples of D1 were heated to $650^{\circ} \mathrm{C}$ for $1 \mathrm{~h}$, a temperature at which calcite begins to decompose (Faust, 1950; Yonge, 1982) and water extraction is thus quantitative (Yonge, 1982). In both cases, the extensive heating caused a gas pressure that, if generated by water vapour, would have been approximately equivalent to another $40 \%$ of the cumulative amounts of water released from the samples. However, under these conditions the gas pressure is largely controlled by the generation of $\mathrm{CO}_{2}$ from calcite (Scheidegger et al., 2010), and only a minor fraction of it is actually related to water vapour. We therefore conclude that the water yields from our combined crushing and heating to $480^{\circ} \mathrm{C}$ in the range of $(7-47) \times 10^{-4} \mathrm{~g}$ of water per gram of stalagmite rock (see Table 2) are close to the total water contents of the samples. This conclusion is further corroborated by the similarity of our $480^{\circ} \mathrm{C}$ water yields to literature water yields from total extractions, which range between $(24-100) \times 10^{-4}$ (Yonge, 1982), and (7-47) $\times 10^{-4}$ (Demény et al., 2012) g of water per $g$ of stalagmite rock, respectively.

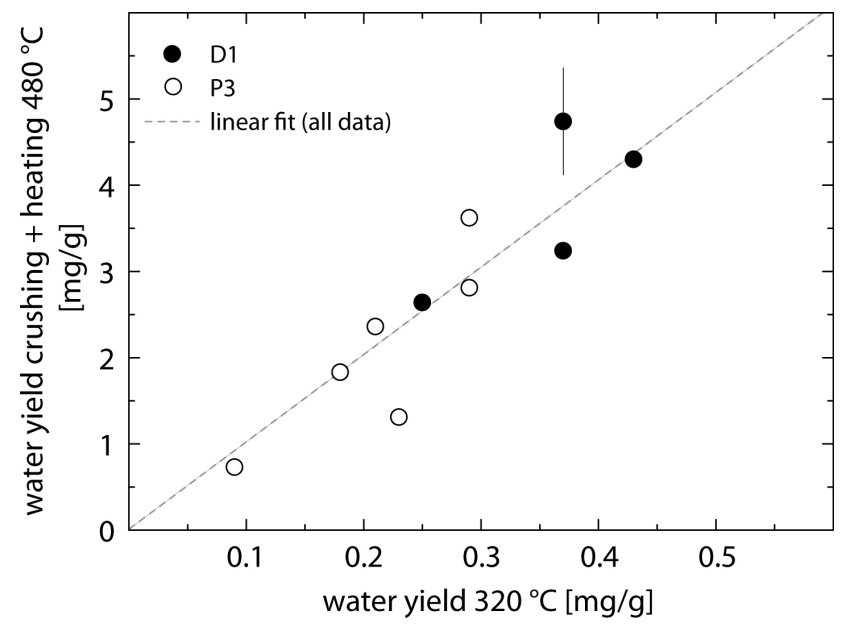

Fig. 3. Comparison of water yields from selected samples of stalagmites $\mathrm{P} 3$ and $\mathrm{D} 1$ resulting from two different extraction techniques. For the $320^{\circ} \mathrm{C}$ extractions, water is released from externally precrushed stalagmite grain size separates that are subsequently heated to $320^{\circ} \mathrm{C}$. For the $480^{\circ} \mathrm{C}$ extractions, samples are vacuum-crushed and subsequently heated to $480^{\circ} \mathrm{C}$. The resulting water yields are linearly correlated (coefficient of determination $r^{2}=0.97$ ). The one sigma uncertainties of water yield determinations are, with one exception, smaller than the symbol sizes.

The experiments show that water extraction from stalagmite samples occurs in a highly systematic manner. The correlation shown in Fig. 3 clearly illustrates that water extracted at $320^{\circ} \mathrm{C}$ is primarily a function of the total amount of water trapped in the rock. A changing water yield within a stalagmite therefore has to be attributed primarily to a changing total water content of the rock, but not, e.g. to a change of the crystal fabric of a rock with a uniform total water amount, in which water extraction is merely alleviated or hampered based on the type of fabric.

\subsection{Digital image analysis}

Optical inspection of stalagmite thin sections was performed using a Zeiss Axioplan 2 optical microscope equipped with a DeltaPix camera and software. Thin sections were prepared from parts of stalagmites D1 (thin sections D1-A, -B, -C) and P3 (thin sections P3-A, -B) characterized by higher and lower water yields, respectively, in order to compare measured water yields with fractions of inclusions estimated from optical inspection (see Fig. 2 for locations of thin section in stalagmites D1 and P3). For stalagmite Y99, no thin sections were available. All thin sections studied here showed that inclusions were numerous and heterogeneous in size, shape, and distribution. Thus, neither counting nor a distinction into (originally) water- and gas-filled inclusions was practicable. Therefore, $8-16$ microphotographs were taken at suitable magnifications and under transmitted light for each of the thin sections and were transformed into black and white 


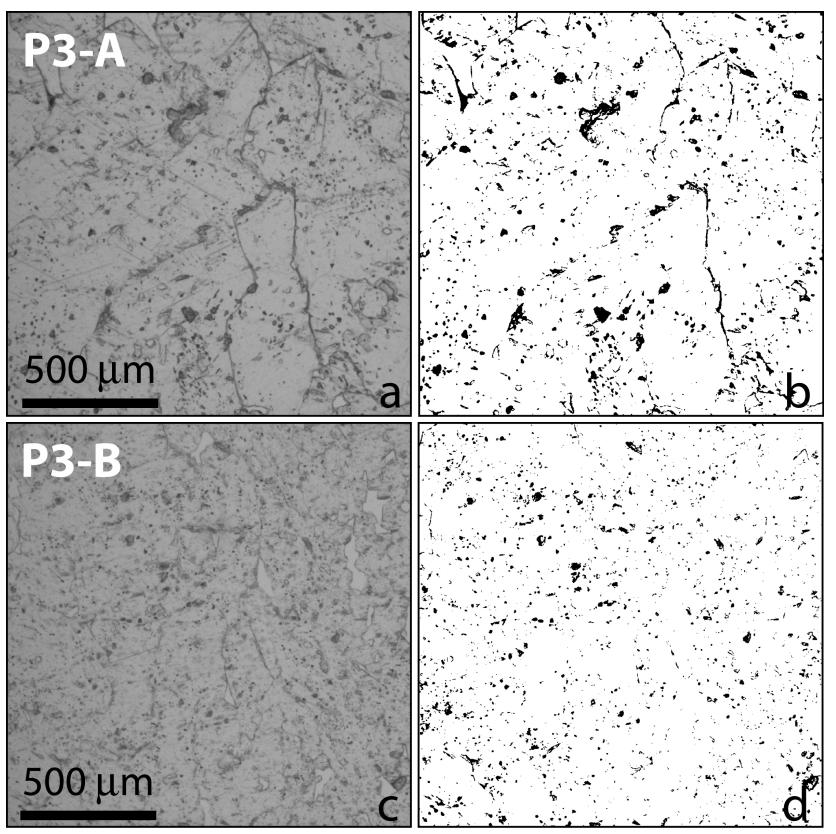

Fig. 4. Examples of microphotographs of stalagmite thin sections P3-A (a) and P3-B (c) characterized by higher and lower water yields, respectively. Also shown are their respective processed black and white images (b, d), in which inclusions at the thin sections' surface are visible as black pixels. Images (b) (P3-A) and (d) (P3B) show $6.8 \%$ and $4.3 \%$ of black pixels, respectively. Note that these numbers do refer to the actual shown microphotographs and can deviate from the mean volume fractions of fluid inclusions given in Sect. 3.2, which average over 8 to 16 individual images.

images applying a greyscale threshold (see Figs. 4 and 5). The threshold was selected such that only inclusions at the immediate surface (i.e. open cavities and inclusions located within the uppermost few microns of the sections), and not those from deeper parts of the sections, appeared as black areas in the processed images. For all P3 images the same threshold value was used, for D1 images the threshold values varied slightly due to variable greyscale distributions of the original photographs. Subsequently, the fraction of black pixels was determined for each image, and the results from all images of the same thin section were averaged. The resulting mean values (given with the respective standard errors of the means in Sect. 3.2) served as an estimate of the fraction of fluid inclusions in the stalagmite. We thereby implicitly assume that a sample with a high fraction of fluid inclusions (i.e. comprising both water- and gas-filled inclusions) is also characterized by a high fraction of water-filled inclusions alone, and vice versa. This assumption seems also justified based on the general similarity of the results from pixel counts and water content measurements, as described in Sect. 3.2.

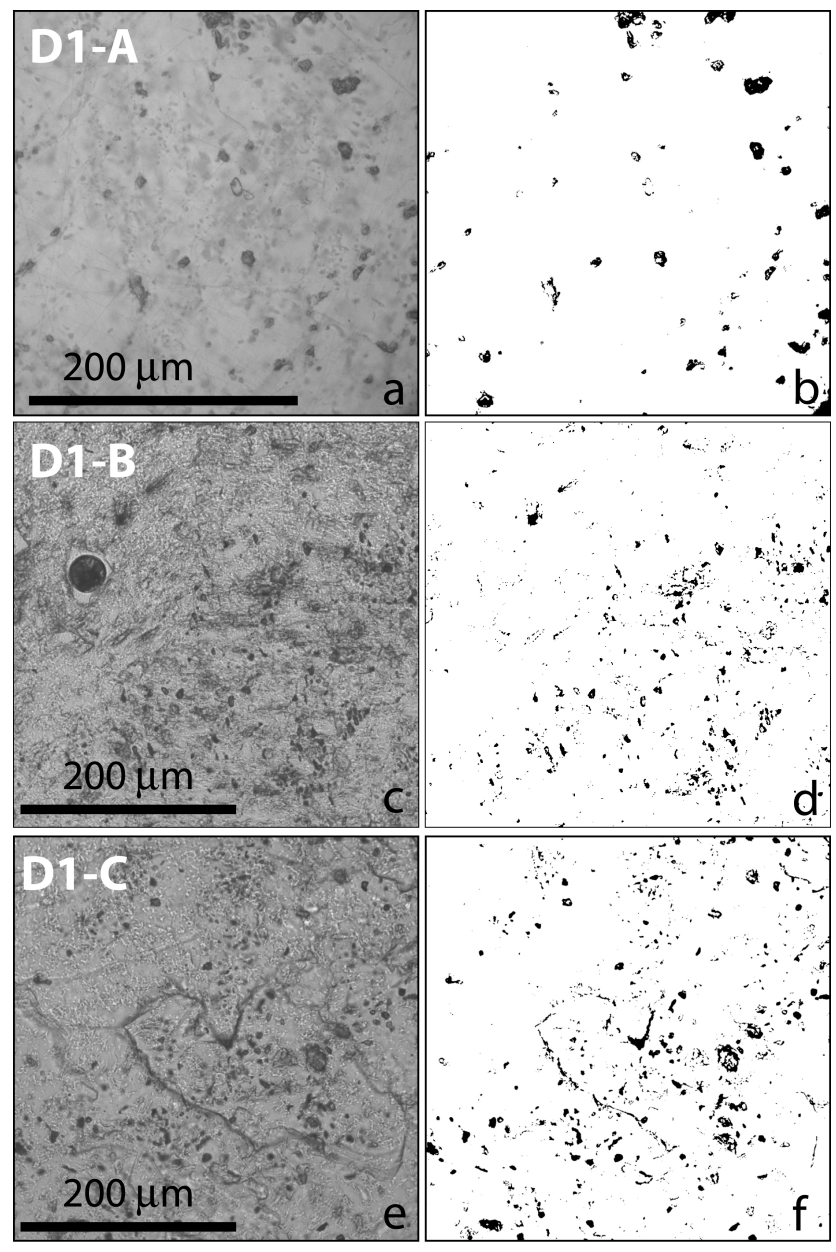

Fig. 5. Examples of microphotographs of stalagmite thin sections D1-A (a) and D1-B (c), both characterized by lower water yields, and thin section D1-C (e) from an area characterized by higher water yields. Also shown are the respective processed black and white images $(\mathbf{b}, \mathbf{d}, \mathbf{f})$. The large dark circle in photograph D1-B (c) is an artefact from thin section production and was not taken into account for black pixel counting. Images (b) (D1-A) and (d) (D1-B) show lower percentages of black pixels $(2.3 \%$ and $2.7 \%$, respectively) than image (f) (D1-C, $4.8 \%$ ). Note that these numbers do refer to the actual shown microphotographs and thus can deviate from the mean volume fractions of fluid inclusions given in Sect. 3.2, which average over 8 to 16 individual images.

\section{Results}

\subsection{Water yields and oxygen isotopes}

Figure 6 shows for D1, P3, and Y99 the correlations of water yields with $\delta^{18} \mathrm{O}_{\text {calcite }}$ values. For this comparison, the resolutions of both parameters had to be harmonized, because samples for water yield analyses were taken with spatial resolutions of $1 \mathrm{~cm}$, while samples for oxygen isotope measurements were taken at resolutions of about $2 \mathrm{~mm}$ (D1), $5 \mathrm{~mm}(\mathrm{P} 3)$, and $1 \mathrm{~mm}$ (Y99). Therefore, $\delta^{18} \mathrm{O}_{\text {calcite }}$ values 
were averaged such that each water yield data point was compared with the mean of the spatially closest 5 (D1), 3 (P3), and 9 (Y99) $\delta^{18} \mathrm{O}_{\text {calcite }}$ values. The uncertainties associated with those mean $\delta^{18} \mathrm{O}_{\text {calcite }}$ values are the respective standard errors of the means. Fitting straight lines to the data by errorweighted least squares regression, we obtain slopes (with $1 \sigma$ errors) of $2.6 \pm 0.2,0.8 \pm 1.1$, and $1.2 \pm 0.2$ for $\mathrm{D} 1, \mathrm{P} 3$, and Y99, respectively. The slopes obtained for D1 and Y99 are clearly inconsistent with a slope of zero, but the errorweighted fit to the P3 data shows no statistically significant correlation between water yield and $\delta^{18} \mathrm{O}_{\text {calcite. The missing }}$ correlation in the case of $\mathrm{P} 3$ is mostly attributed to the coarse spatial resolution of the $\mathrm{P} 3 \delta^{18} \mathrm{O}_{\text {calcite }}$ record, which results in large errors of the averaged values (including only three individual values each). The coarse resolution of the $\delta^{18} \mathrm{O}_{\text {calcite }}$ record is particularly problematic in the upper part of stalagmite P3 where successive individual $\delta^{18} \mathrm{O}_{\text {calcite values vary }}$ substantially. If these errors are not taken into account, the (non-error-weighted) fit to the P3 data results in a slope of the correlation line of $3.2 \pm 1.5$, which is different from zero even on the $2 \sigma$ level (solid line in Fig. 6b). We further compare by applying F-tests to the two models "linear trend" (using the error-weighted least squares regressions) and "no trend" (using error-weighted mean values) for each of the three data sets. For D1 and Y99 the results clearly show that the "no trend" model should be rejected in favour of the "linear trend" model for D1 ( $p=<0.001)$ and Y99 $(p=0.002)$; however, this is not the case for P3 $(p=0.98)$. For P3 the same test was repeated using non-error-weighted fits. In this case for P3 the "no trend" model should also clearly be rejected in favour of the "linear trend" model ( $p=0.008)$.

In summary, highly significant correlations exist between the parameters water yield and $\delta^{18} \mathrm{O}_{\text {calcite }}$ for $\mathrm{D} 1$ and $\mathrm{Y} 99$, with low water yields corresponding to low $\delta^{18} \mathrm{O}_{\text {calcite }}$ values and vice versa. The same is true for $\mathrm{P} 3$, but the correlation is obscured to a certain degree by the large errors of the average $\delta^{18} \mathrm{O}_{\text {calcite }}$ values caused by the coarse spatial resolution of the $\mathrm{P} 3$ oxygen isotope record.

In the following sections (3.1.1-3.1.3) the correlations between water yield and oxygen isotopic composition were further assessed by applying parametric Sequential t t-test Analyses of Regime Shifts (STARS, Rodionov, 2004; Rodionov and Overland, 2005) to determine regime shift points in the stalagmites' $\delta^{18} \mathrm{O}_{\text {calcite }}$ records. Thereby, the targeted significance level $p$ was predefined to 0.05 and for the window length $L$ we used 10,20, and 30 data points, respectively. The most prominent regime shift point for each $\delta^{18} \mathrm{O}_{\text {calcite }}$ record is shown as a dashed red line in Fig. 7. Subsequently, the water yield and $\delta^{18} \mathrm{O}_{\text {calcite }}$ values on both sides of the respective major shift points were compared with each other by means of a Student's t-test. Also mean values with standard errors of the means for all oxygen and water yield data prior to and after the respective major regime shift points are given in Fig. 7 and visualized as grey areas in the plots.
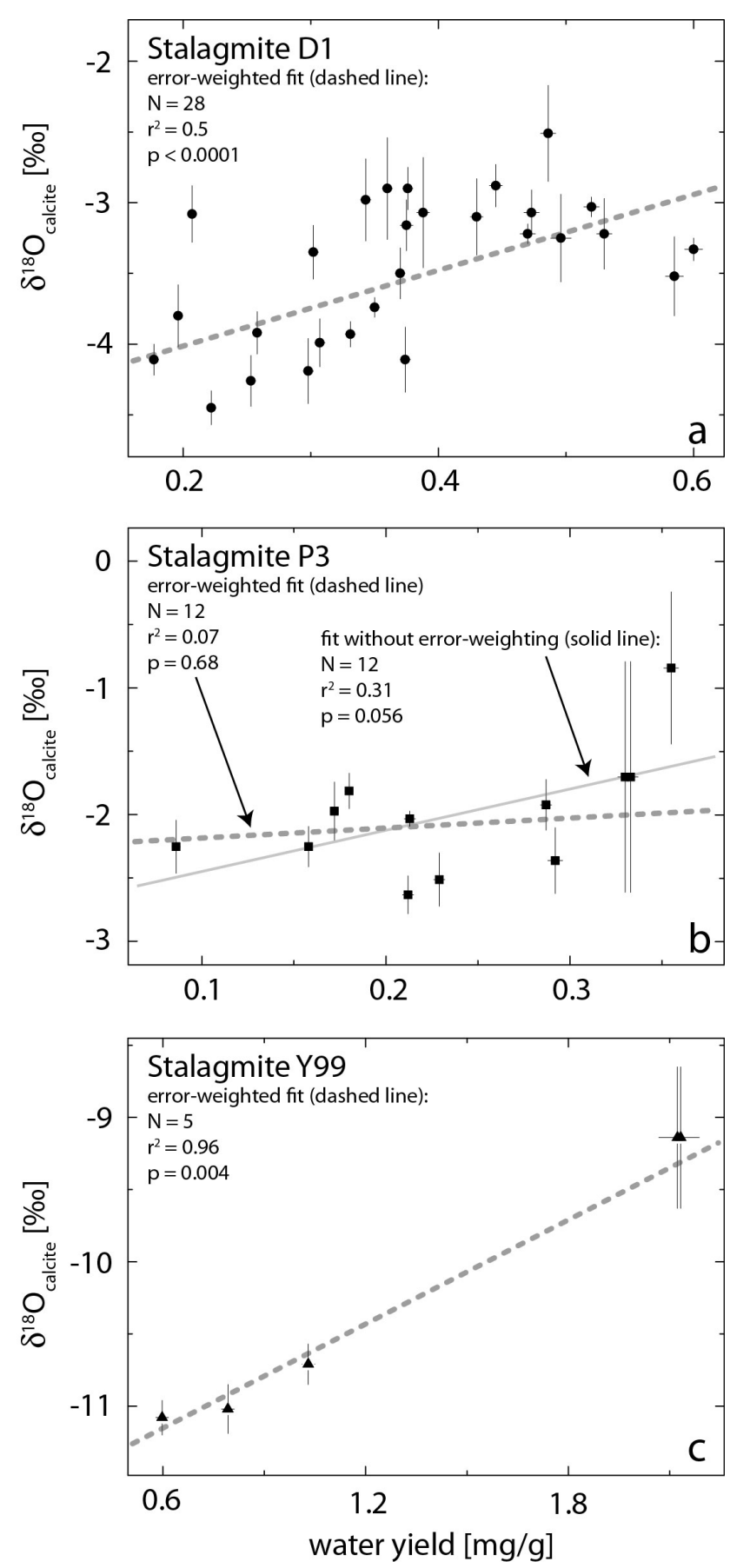

Fig. 6. Correlation between water yield and $\delta^{18} \mathrm{O}_{\text {calcite }}$ for stalagmites D1 (a), P3 (d), and Y99 (c). Water was extracted at $320^{\circ} \mathrm{C}$ for D1 and P3 samples, and at $400{ }^{\circ} \mathrm{C}$ for Y99 samples. Dashed lines represent error-weighted fits; the solid line in Fig. $6 \mathrm{~b}$ represents a non-error-weighted fit. $N=$ number of data points; $r^{2}=$ coefficient of determination; $p=$ significance level. Error bars of $\delta^{18} \mathrm{O}_{\text {calcite }}$ values represent standard errors of mean values. Error bars associated to water yield data (see Table 2 and Sect. 2.4) are often smaller than the symbol sizes. 

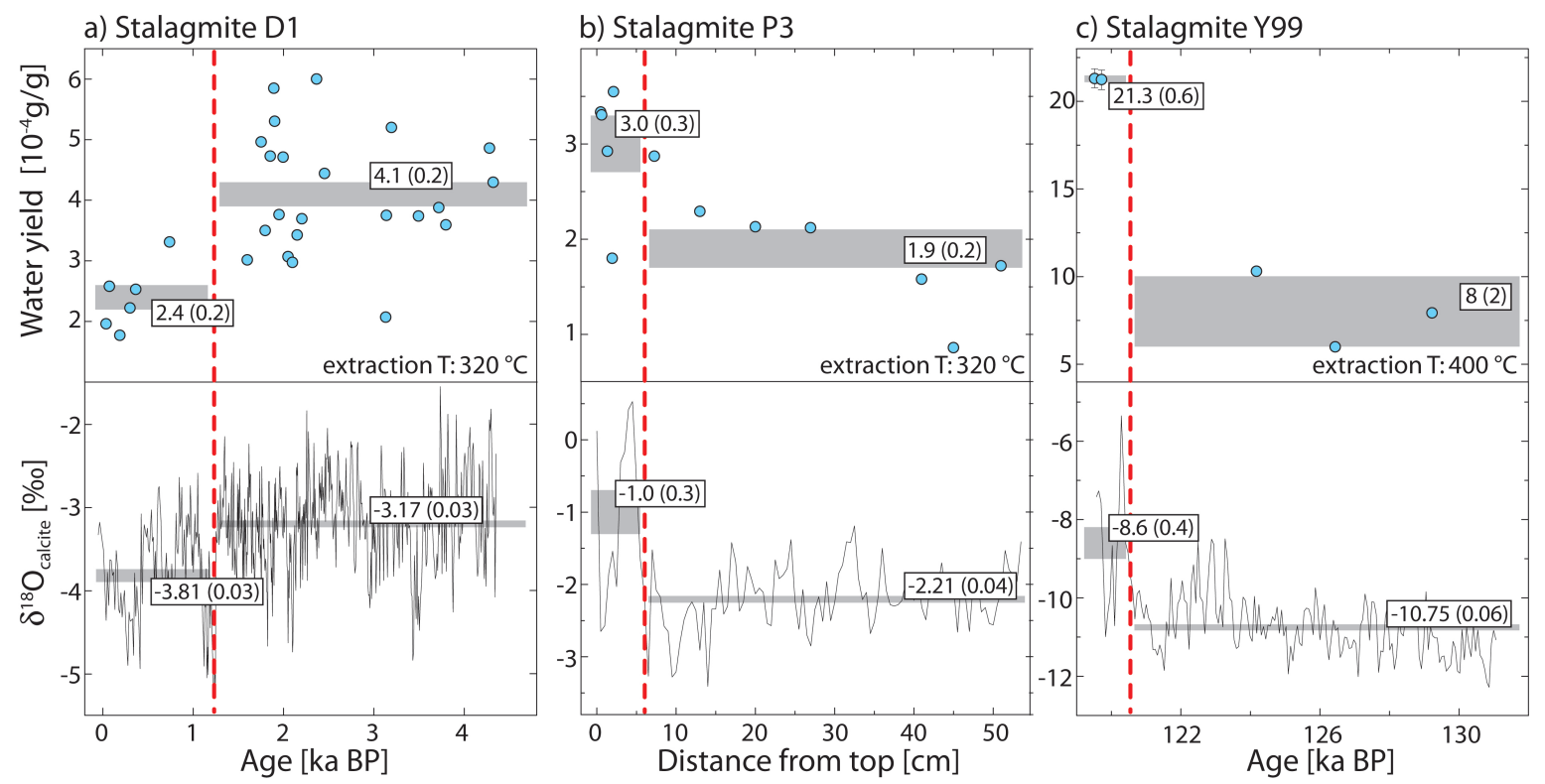

Fig. 7. Water yield and oxygen isotopic compositions of stalagmite D1 (a), P3 (b), and Y99 (c) plotted as functions of sample age (D1, Y99), and distance from top (P3). Dashed red lines refer to the major regime shift points as defined from the $\delta^{18} \mathrm{O}_{\text {calcite }}$ data using STARS (Rodionov, 2004). Numbers in squares represent mean values with standard errors of the means of the data points on both sides of the major regime shift points, respectively. The means are also visualized as grey squares in the plots, the height of the squares corresponding to the standard errors of the means.

\subsubsection{Stalagmite D1 (Fig. 7a)}

The $\mathrm{D} 1 \delta^{18} \mathrm{O}_{\text {calcite }}$ ranges around values of about $-3 \%$ between 4.35 and $1.3 \mathrm{ka} \mathrm{BP}$, followed by an overall decrease of the $\delta^{18} \mathrm{O}_{\text {calcite }}$ values between $1 \mathrm{ka} \mathrm{BP}$ to the present. STARS determines the major regime shift point in the D1 oxygen isotope record at $1.25 \mathrm{ka} \mathrm{BP}$, which corresponds to a pronounced negative excursion with $\delta^{18} \mathrm{O}_{\text {calcite }}$ values as low as $-5.3 \%$. Note that each of the different window lengths applied resulted in the same major regime shift point. Application of the Student's t-test shows that the $\mathrm{D} 1 \delta^{18} \mathrm{O}_{\text {calcite }}$ values prior to and after the major regime shift point are significantly different from each other at the $1 \%$ level. Accordingly, also the water yields on both sides of the major regime shift point (as defined via the $\delta^{18} \mathrm{O}_{\text {calcite }}$ data) are different from each other at the $1 \%$ level.

\subsubsection{Stalagmite P3 (Fig. 7b)}

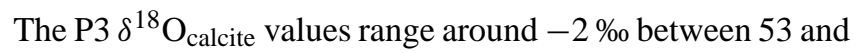
$7 \mathrm{~cm}$ from the top of the stalagmite. In contrast, the character of the $\delta^{18} \mathrm{O}_{\text {calcite }}$ record of the uppermost few centimeters of $\mathrm{P} 3$ is clearly different, showing a distinctly larger variability of $\delta^{18} \mathrm{O}_{\text {calcite }}$ values over small distances with individual values of up to $+0.5 \%$. STARS detects the major regime shift point at $6 \mathrm{~cm}$ distance from the top of the stalagmite, again using window lengths $L$ of 10,20 , and 30 data points, respectively. Indeed, the P3 $\delta^{18} \mathrm{O}_{\text {calcite }}$ values on both sides of the regime shift point are significantly different from each other at the $1 \%$ level. Also, the water yield values on both sides of the regime shift point at $6 \mathrm{~cm}$ distance from the top are different from each other at the $5 \%$ significance level.

\subsubsection{Stalagmite Y99 (Fig. 7c)}

The $\mathrm{Y} 99 \delta^{18} \mathrm{O}_{\text {calcite }}$ values range around $-11 \%$ o between 131 and $121 \mathrm{ka} \mathrm{BP}$. Like P3, also Y99 shows in its youngest part (121-119 ka BP) a distinctly larger variability of $\delta^{18} \mathrm{O}_{\text {calcite }}$ values over small distances with individual values of up to $-6 \%$. For this $\delta^{18} \mathrm{O}_{\text {calcite }}$ record, STARS detects the major regime shift point at $120.6 \mathrm{ka} \mathrm{BP}$. The $\delta^{18} \mathrm{O}_{\text {calcite }}$ values on both sides of this shift point location are significantly different from each other at the sub-permil level. Also, the water yields prior to and after the major regime shift point are different from each other at a significance level of $1 \%$.

As shown in Fig. 7, for all three stalagmites low mean water yields correlate with low mean $\delta^{18} \mathrm{O}_{\text {calcite }}$ and vice versa. This also corroborates the results from the direct correlation tests of both parameters described above and shown in Fig. 6.

\subsection{Relationship between water yield and the occurrence of microscopically detectable fluid inclusions}

Image-processed microphotographs of thin sections were used to optically estimate area fractions of fluid inclusions (represented by the percentages of black pixels in the images) from parts of stalagmites D1 and P3 characterized by 
high and low water yields, respectively. In the following we implicitly assume the actual area fractions do represent the respective volume fractions of fluid inclusions in the stalagmite samples.

Thin sections D1-A and D1-B were prepared from the upper part of stalagmite D1 characterized by low water yields. The mean volume fractions of fluid inclusions for D1-A and D1-B are $(2.6 \pm 0.3) \%$ and $(2.7 \pm 0.3) \%$, respectively. Thin section D1-C was prepared from the lower part of the stalagmite characterized by high water yields, and also shows a higher mean volume fraction of fluid inclusions of $(3.7 \pm 0.3) \%$ compared to D1-A and -B. For thin section P3A, prepared from the top of the stalagmite with overall high water yields, the mean volume fraction of fluid inclusions is $(2.4 \pm 0.4) \%$. Thin section P3-B, prepared from a lower part of the stalagmite characterized by low water yields, nominally shows a lower mean volume fraction of fluid inclusions of $(2.0 \pm 0.8) \%$, which is, however, not outside the given uncertainties.

Note that the volume fractions of fluid inclusions deduced from pixel counts are somewhat higher but not too different from the volume fractions of water in the studied stalagmites calculated from our $480^{\circ} \mathrm{C}$ extractions, which range between $0.2-1.2$ vol. \%. The systematic offset between results from optical inspection and water yield measurement is largely attributed to the fact that the former method also counts air inclusions (and other impurities causing black pixels) in addition to the water-filled inclusions.

The results from optical inspection of thin sections basically support the trends deduced from our actual water yield measurements. For both stalagmites, those parts characterized by high water yields also show large volume fractions of fluid inclusions and vice versa. Nonetheless, we emphasize that especially the selection of appropriate threshold values to distinguish fluid inclusions (both air- and water-filled) from other features (e.g. surface roughness) of the thin sections is to a certain degree subject to the examiner's personal judgement, which might bias the respective results. Thus, in order to infer for a given set of stalagmite samples a reliable record of water contents, extraction of inclusion water under uniform experimental conditions is certainly preferable to the more subjective tool of microscopic inspection of thin sections.

\section{Water yield, oxygen isotopes, and drip water supply}

Numerous oxygen isotope studies on stalagmites from Yemen and Oman have shown that $\delta^{18} \mathrm{O}_{\text {calcite }}$ records reflect rainfall rates in the area with decreasing $\delta^{18} \mathrm{O}_{\text {calcite }}$ values indicating increasing rainfall rates and vice versa (e.g. Burns et al., 2001, 1998; Fleitmann et al., 2003a, b, 2004, 2007, 2011b).

The oxygen isotope record of stalagmite D1 is characterized by fairly constant rainfall on Socotra Island between 4.3 to $1.2 \mathrm{ka}$ BP. From $1.2 \mathrm{ka} \mathrm{BP}$ to the present, $\delta^{18} \mathrm{O}_{\text {calcite }}$ values decrease, which indicates, according to the "amount-effect", an increase in rainfall rates (cf. Fleitmann et al., 2011a, b, 2007). Note that the change of climatic conditions on Socotra Island coincides with a recovery from arid conditions in continental Arabia (e.g. Fleitmann et al., 2011a; Parker and Rose, 2008).

Also, the $\delta^{18} \mathrm{O}_{\text {calcite }}$ pattern of stalagmite P3 implies fairly constant rainfall over large parts of the record. The uppermost few centimeters of P3 are characterized by rapidly changing $\delta^{18} \mathrm{O}_{\text {calcite }}$ values over short distances, including two prominent excursions to high $\delta^{18} \mathrm{O}_{\text {calcite }}$ values at around $4.5 \mathrm{~cm}$ and $0 \mathrm{~cm}$ from the top of the stalagmite. The peak at $4.5 \mathrm{~cm}$ correlates with a distinctive dark layer indicative of a growth hiatus (see Figs. 2 and $7 \mathrm{~b}$ ). The second increase of $\delta^{18} \mathrm{O}_{\text {calcite }}$ at $0 \mathrm{~cm}$ correlates with the final termination of stalagmite growth. A corresponding carbon isotope record of stalagmite P3 (not shown) shows two excursions towards high $\delta^{13} \mathrm{C}_{\text {calcite }}$ values synchronous with the positive $\delta^{18} \mathrm{O}_{\text {calcite }}$ peaks. We conclude that the excursions to higher, i.e. heavier, isotopic compositions for both oxygen and carbon are the result of reduced drip water availability, leading to higher rates of $\mathrm{CO}_{2}$ degassing from the water film on top of stalagmite $\mathrm{P} 3$. This process is known to cause simultaneous enrichment of ${ }^{13} \mathrm{C}$ and ${ }^{18} \mathrm{O}$ in the precipitating calcite (e.g. Baker et al., 1997; Hendy, 1971). Due to the poorly constrained chronology of this stalagmite, the regime shift recorded in P3 cannot be linked to changing regional paleoclimatic conditions.

The interpretation of the section of Y99 studied here is similar to that of P3. Between 131 and $121 \mathrm{ka} \mathrm{BP}$, high rainfall rates lead to the lowest mean $\delta^{18} \mathrm{O}_{\text {calcite }}$ values found in the stalagmite (cf. Fleitmann et al., 2011b). The time span between 121 and $119 \mathrm{ka}$ BP is characterized by strongly variable $\delta^{18} \mathrm{O}_{\text {calcite }}$ values including prominent excursions to higher, i.e. heavier, $\delta^{18} \mathrm{O}_{\text {calcite }}$ values similar to those found in P3. This implies an overall reduction of drip water supply between 121 and $119 \mathrm{ka} \mathrm{BP}$, ultimately followed by the termination of growth of stalagmite Y99 and the onset of a dry period in continental Yemen lasting until $\sim 105 \mathrm{ka}$ BP (Fleitmann et al., 2011b).

The interpretation of $\delta^{18} \mathrm{O}_{\text {calcite }}$ in terms of drip water supply allows establishing a link between water yields of the studied stalagmites and drip rates. $\delta^{18} \mathrm{O}_{\text {calcite }}$ in $\mathrm{D} 1$ indicates a period of constant rainfall rates, implying a constant drip water supply between 4.3 and $1.2 \mathrm{ka}$ BP. During the last $1 \mathrm{ka} \mathrm{BP}$, rainfall, and therefore also the drip rates for D1, increase. During the same time interval, D1 shows reduced water yields in the respective stalagmite samples. Therefore, we infer that the fraction of water-filled inclusions (governing the water yield of a given sample) in the stalagmite is reduced during times of higher drip water supply. The $\mathrm{P} 3$ and $\mathrm{Y} 99 \delta^{18} \mathrm{O}_{\text {calcite }}$ data both indicate phases of fairly constant rates of rainfall and therefore constant drip rates. These are followed by periods of lower rainfall rates and 
thus lower drip rates recorded in the uppermost few $\mathrm{cm}$ of the two stalagmites, respectively. For both stalagmites, these uppermost parts are also characterized by the highest water yields. Consequently, we conclude that a reduction of drip water supply increases the fraction of water-filled inclusions in the growing stalagmite.

This conclusion might at first seem to be "counterintuitive". However, our observations are supported by several studies on stalagmite growth and formation of stalagmite fluid inclusions (e.g. Fairchild et al., 2008; Frisia et al., 2000; Genty and Quinif, 1996; Yonge, 1982). The studies agree that a high (and therefore continuous) supply of drip water, being usually characterized by low calcium ion supersaturation (e.g. Sherwin, 2011), supports a slow and constant growth of calcite crystals, which results in a low density of crystal defects. Such "ideal" crystal growth conditions lead to a low porosity and therefore a low fraction of fluid inclusions in the calcite precipitate. Conversely, low drip rates (with high calcium ion supersaturation of the water) lead to a more effective degassing of $\mathrm{CO}_{2}$ from the drip water, which in turn causes faster carbonate precipitation. In addition, low drip rates can cause periodic exposure of the growing crystals to the cave air. Both effects result in a "non-ideal" crystal growth and therefore a higher porosity and a larger fraction of fluid inclusions in the calcite fabric (Fairchild et al., 2008; Frisia et al., 2000; Genty and Quinif, 1996). Also, Yonge (1982) speculated that faster carbonate precipitation leads to higher porosity in the growing stalagmite, which in turn fosters the trapping of larger fractions of drip water in the rock.

\section{Conclusions and outlook}

We present water yield measurements serving as proxy measures of the total water content of stalagmite samples, together with oxygen isotope records, for two Holocene stalagmites from Socotra Island, Yemen, and one Eemian stalagmite from southern continental Yemen. Water yield measurements are qualitatively supported by the volume fractions of fluid inclusions in the stalagmites estimated from optical inspection of stalagmite thin sections. Water yields vary systematically with changes in the oxygen isotopic compositions of a given stalagmite. Thereby, isotopically light oxygen is accompanied by low water yields and vice versa. Based on the paleo-climatic interpretation of the stalagmites' $\delta^{18} \mathrm{O}_{\text {calcite }}$ records in terms of drip water supply, we infer that stalagmite samples characterized by low water yields formed during times of increased and therefore, specifically in arid and semi-arid areas, more continuous drip water supply, allowing undisturbed calcite growth and thus leading to inclusion-poor stalagmite rock and vice versa. We therefore propose that for stalagmites from hot and rather dry areas, water yield records allow direct conclusions on changes in drip rates which in turn can be used to track changes in the rates of rainfall. However, prior to a routine application of this proposed new paleo-climate proxy, additional experiments would be desirable to further constrain the correlation (and the underlying reasons) between $\delta^{18} \mathrm{O}_{\text {calcite }}$ and water yield, for example by analyzing both parameters on aliquots of the same sample. Also, further studies, like e.g. the one of Demény et al. (2012), will have to prove whether or not this new paleo-climate proxy is also applicable to stalagmites grown under different, for example cooler and more humid climatic conditions.

Acknowledgements. The authors would like to thank U. Menet and $\mathrm{H}$. Baur for their assistance in the noble gas laboratory at ETH Zurich. We also thank Y. Krüger (University of Bern) for his valuable input concerning the formation of fluid inclusions. We are grateful to M. G. Fellin for her help with and frequent access to various optical microscopes at ETH Zurich. Inspiring and helpful discussions with all members of the Environmental Isotope Group at Eawag are greatly acknowledged, as are comments on an earlier version of the manuscript by anonymous reviewers. This study was carried out within the framework of the Sinergia project "STALCLIM" funded by the Swiss National Science Foundation (grant no. CRSI22-132646/1 to D. Fleitmann and co-PI's).

Edited by: G. Lohmann

\section{References}

Baker, A., Ito, E., Smart, P. L., and McEwan, R. F.: Elevated and variable values of ${ }^{13} \mathrm{C}$ in speleothems in a British cave system, Chem. Geol., 136, 263-270, 1997.

Burns, S. J., Matter, A., Frank, N., and Mangini, A.: Speleothembased paleo-climate record from northern Oman, Geology, 26, 499-502, 1998.

Burns, S. J., Fleitmann, D., Matter, A., Neff, U., and Mangini, A.: Speleothem evidence from Oman for continental pluvial events during interglacial periods, Geology, 29, 623-626, 2001.

Cheng, H., Edwards, R. L., Broecker, W. S., Denton, G. H., Kong, X., Wang, Y., Zhang, R., and Wang, X.: Ice age terminations, Science, 326, 248-252, 2009.

Clark, I. D. and Fritz, P. E.: Environmental Isotopes in hydrology, CRC press LLC, New York, 1997.

Clemens, C. C., Prell, W. L., and Sun, Y.: Orbital-scale timing and mechanisms driving Late Pleistocene Indo-Asian summer monsoons: reinterpreting cave speleothem $\delta^{18} \mathrm{O}$, Paleoceanography, 25, PA4207, doi:10.1029/2010PA001926, 2010.

Cosford, J., Quing, H., Mattey, D., Eglington, B., and Zhang, M.: Climatic and local effects on stalagmite $\delta^{13} \mathrm{C}$ values at Lianhua Cave, China, Palaeogeogr. Palaeocl., 280, 235-244, 2009.

Demény, A., Czuppon, G., Siklosy, Z., Leél-Össy, S., Lin, K., Shen, C.-C., and Gulyas, K.: Mid-Holocene climate conditions and moisture source variations based on stable $\mathrm{H}, \mathrm{C}$, and $\mathrm{O}$ isotope compositions of speleothems in Hungary, Quarternary Int., in press, 2012.

Dong, J., Wang, Y., Cheng, H., Hardt, B., Edwards, R. L., Kong, X., Wu, J., Chen, S., Liu, D., Jiang, X., and Zhao, K.: A high-resolution stalagmite record of the Holocene East Asian 
monsoon from Mt Shennongjia, central China, Holocene, 20, 257-264, 2010.

Dorale, J. A., Edwards, R. L., Ito, E., and Gonzales, L. A.: Climate and vegetation history of the midcontinent from 75 to $25 \mathrm{ka}$ : a speleothem record from Crevice Cave, Missouri, USA, Science, 282, 1871-1874, 1998.

Fairchild, I. J., Frisia, S., Borsato, A., and Tooth, A. F.: Speleothems, in: Geochemical sediments and landscapes, edited by: Nash, D. J. and McLaren, S. J., Blackwell Publishing Ltd., Oxford, UK, 200-245, 2008.

Faust, G. T.: Thermal analysis studies on carbonates: 1. Aragonite and calcite, Am. Mineral., 35, 207-224, 1950.

Fleitmann, D., Burns, S. J., Mudelsee, M., Neff, U., Kramers, J., Mangini, A., and Matter, A.: Holocene forcing on the Indian monsoon recorded in a stalagmite from southern Oman, Science, 300, 1737-1739, 2003a.

Fleitmann, D., Burns, S. J., Neff, U., Mangini, A., and Matter, A.: Changing moisture sources over the last 330,000 years in northern Oman from fluid-inclusions evidence in speleothems, Quarternary Res., 60, 223-232, 2003 b.

Fleitmann, D., Burns, S. J., Neff, U., Mudelsee, M., Mangini, A., and Matter, A.: Paleoclimatic interpretation of highresolution oxygen isotope profiles derived from annually laminated speleothems from Southern Oman, Quarternary Sci. Rev., 23, 935-945, 2004.

Fleitmann, D., Burns, S. J., Mangini, A., Mudelsee, M., Kramers, J., Villa, I., Neff, U., Al-Subbary, A. A., Buettner, A., Hippler, D., and Matter, A.: Holocene ITCZ and Indian monsoon dynamics recorded in stalagmites from Oman and Yemen (Socotra), Quarternary Sci. Rev., 26, 170-188, 2007.

Fleitmann, D., Cheng, H., Badertscher, S., Edwards, R. L., Mudelsee, M., Göktürk, O. M., Fankhauser, A., Pickering, R., Raible, C. C., Matter, A., Kramers, J., and Tüysüz, O.: Timing and climatic impact of Greenland interstadials recorded in stalagmites from northern Turkey, Geophys. Res. Lett., 36, L19707, doi:10.1029/2009GL040050, 2009.

Fleitmann, D., Bradley, R. S., Burns, S. J., Mudelsee, M., Cheng, H., Edwards, R. L., Mangini, A., and Matter, A.: Megadroughts at the dawn of Islam recorded in a stalagmite from northern Oman, Mineral. Mag., 75, p. 853 (Abstract), 2011a.

Fleitmann, D., Burns, S. J., Pekala, M., Mangini, A., Al-Subbary, A. A., Al-Aowah, M., Kramers, J., and Matter, A.: Holocene and Pleistocene pluvial periods in Yemen, southern Arabia, Quarternary Sci. Rev., 30, 783-787, 2011b.

Frisia, S., Borsato, A., Fairchild, I. J., and McDermott, F.: Calcite fabrics, growth mechanisms, and environments of formation in speleothems from the Italian Alps and southwestern Ireland, J. Sediment. Res., 70, 1183-1196, 2000.

Genty, D. and Quinif, Y.: Annually laminated sequences in the internal structure of some Belgian stalagmites - importance for paleoclimatology, J. Sediment. Res., 66, 275-288, 1996.

Griffith, M. L., Drysdale, R. N., Vonhof, H. B., Gagan, M. K., Zhao, J., Ayliffe, L. K., Hantoro, W. S., Hellstorm, J. C., Cartwright, I., Frisia, S., and Suwargadi, W.: Younger Dryas - Holocene temperature and rainfall history of southern Indonesia from $\delta^{18} \mathrm{O}$ in speleothem calcite and fluid inclusions, Earth Planet. Sci. Lett., 295, 30-36, 2010.
Harmon, R. S., Schwarcz, H. P., and O’Neil, J. R.: D/H ratios in speleothem fluid inclusions: a guide to variations in the isotopic composition of meteoric precipitation, Earth Planet. Sci. Lett., 42, 254-266, 1979.

Henderson, G. M.: Caving in to new chronologies, Science, 313, 620-622, 2006.

Hendy, C. H.: The isotopic geochemistry of speleothems - I. The calculation of the effects of different modes of formation on the isotopic composition of speleothems and their applicability as paleoclimatic indicators, Geochim. Cosmochim. Acta, 35, 801824, 1971.

Kluge, T., Marx, T., Scholz, D., Niggemann, S., Mangini, A., and Aeschbach-Hertig, W.: A new tool for paleo-climate reconstruction: noble gas temperatures from fluid inclusions in speleothems, Earth Planet. Sci. Lett., 269, 408-415, 2008.

LeGrande, A. N. and Schmidt, G. A.: Sources of Holocene variability of oxygen isotopes in paleoclimate archives, Clim. Past, 5, 441-455, doi:10.5194/cp-5-441-2009, 2009.

Liu, D., Wang, Y., Cheng, H., Edwards, R. L., Kong, X., Wang, X., Hardt, B., Wu, J., Chen, S., Jiang, X., He, Y., Dong, J., and Zhao, K.: Sub-millennial variability of Asian monsoon intensity during the early MIS 3 and its analogue to the ice age terminations, Quarternary Sci. Rev., 29, 1107-1115, 2010.

McDermott, F., Schwarcz, H. P., and Rowe, P. J.: Isotopes in Speleothems, in: Isotopes in paleoenvironmental research, edited by: Leng, M. J., Springer, Dordrecht, The Netherlands, 307, 185225, 2006.

McGarry, S., Bar-Matthews, M., Matthews, A., Vaks, A., Schilmann, B., and Ayalon, A.: Constraints on hydrological and paleotemperature variations in the eastern Mediterranean region in the last $140 \mathrm{ka}$ given by the $\delta \mathrm{D}$ values of speleothem fluid inclusions, Quarternary Sci. Rev., 23, 919-934, 2004.

Parker, A. G. and Rose, J. I.: Climate change and human origins in southern Arabia, Proceedings of the Seminar for Arabian Studies, London, 25-42, 2008.

Rodionov, S. N.: A sequential algorithm for testing climate regime shifts, Geophys. Res. Lett., 31, L09204, doi:10.1029/2004GL019448, 2004.

Rodionov, S. N. and Overland, J. E.: Application of a sequential regime shift detection method to the Bering Sea ecosystem, J. Mar. Sc., 62, 328-332, 2005.

Scheidegger, Y.: The use of noble gases in stalagmite fluid inclusions as proxies for the cave temperature, $\mathrm{PhD}$, ETH Zurich, Zurich, 95 pp., 2011.

Scheidegger, Y. M., Baur, H., Brennwald, M. S., Fleitmann, D., Wieler, R., and Kipfer, R.: Accurate analysis of noble gas concentrations in small water samples and its application to fluid inclusions in stalagmites, Chem. Geol., 272, 31-39, 2010.

Scheidegger, Y. M., Brennwald, M. S., Fleitmann, D., Jeannin, P.Y., Wieler, R., and Kipfer, R.: Determination of Holocene cave temperatures from $\mathrm{Kr}$ and $\mathrm{Xe}$ concentrations in stalagmite fluid inclusions, Chem. Geol., 288, 61-66, 2011.

Scholte, P. and De Geest, P.: The climate of Socotra island (Yemen): a first-time assessment of the timing of the monsoon wind reversal and its influence on precipitation and vegetation patterns, J. Arid Environ., 74, 1507-1515, 2010.

Schwarcz, H. P. and Harmon, R. S.: Stable isotope studies of fluid inclusions in speleothems and their paleoclimatic significance, Geochim. Cosmochim. Acta, 40, 657-665, 1976. 
Shakun, J. D., Burns, S. J., Fleitmann, D., Kramers, J., Matter, A., and Al-Subary, A.: A high-resolution, absolute-dated deglacial speleothem record of Indian Ocean climate from Socotra Island, Yemen, Earth Planet. Sci. Lett., 259, 441-456, 2007.

Sherwin, C. M.: Cave air and hydrological controls on prior calcite precipitation and stalagmite growth rates: Implications for paleo-climate reconstructions using speleothems, Geochim. Cosmochim. Acta, 75, 3915-3929, 2011.

Vaks, A., Bar-Matthews, M., Matthews, A., Ayalon, A., and Frumkin, A.: Middle - Late Quarternary paleo-climate of northern margins of the Saharan-Arabian desert: reconstruction from speleothems of Negev Desert, Israel, Quarternary Sci. Rev., 29, 2647-2662, 2010.
Wang, Y., Cheng, H., Edwards, R. L., Kong, X., Shao, X., Chen, S., Wu, J., Jiang, X., Wang, X., and An, Z.: Millennial- and orbitalscale changes in the east Asian monsoon over the past 224,000 years, Nature, 451, 1090-1093, 2008.

Yonge, C. J.: Stable isotope studies from the water extracted from speleothems, PhD Thesis, McMaster University, 298 pp., 1982.

Zhang, R., Schwarcz, H. P., Ford, D. C., Serefiddin Schroeder, F., and Beddows, P. A.: An absolute paleotemperature record from 10 to $6 \mathrm{ka}$ inferred from fluid inclusion $\mathrm{D} / \mathrm{H}$ ratios of a stalagmite from Vancouver Island, British Columbia, Canada, Geochim. Cosmochim. Acta, 72, 1014-1026, 2008.

Zhao, K., Wang, Y., Edwards, R. L., Cheng, H., and Liu, D.: Highresolution stalagmite $\delta^{18} \mathrm{O}$ records of Asian monsoon changes in central and southern China spanning the MIS 3/2 transition, Earth Planet. Sci. Lett., 298, 191-198, 2010. 